\title{
Microearthquake study of the broader Thessaloniki area (Northern Greece)
}

\author{
Parthena M. Paradisopoulou $\left({ }^{1}\right)$, Vassilis G. Karakostas $\left({ }^{1}\right)$, Eleftheria E. Papadimitriou $\left({ }^{1}\right)$, \\ Markos D. Tranos $\left({ }^{2}\right)$, Costantinos B. Papazachos $\left({ }^{1}\right)$ and Georgios F. Karakaisis $\left({ }^{1}\right)$ \\ ${ }^{1}$ ) Department of Geophysics, School of Geology, \\ Aristotle University of Thessaloniki, Thessaloniki, Greece \\ ${ }^{2}$ ) Department of Geology, School of Geology, \\ Aristotle University of Thessaloniki, Thessaloniki, Greece
}

\begin{abstract}
A temporary network of twelve portable digital seismological stations was operated around the city of Thessaloniki (Northern Greece) for a period of 19 months (from July 2001 to April 2002 and from October 2002 to August 2003), providing data that enabled the study of the interconnection between microseismicity and active tectonics in the area. During the operation period 277 microearthquakes that were recorded in more than four stations were accurately located and 64 fault plane solutions were determined. Seismic activity is associated with ENE-WSW, E-W and ESE-WNW striking normal faults and is nearly confined to the first $15 \mathrm{~km}$, thus defining the seismogenic layer in the study area. The mean orientation of the axis of maximum extension ( $T$-axis) is $\mathrm{N}$ $\mathrm{S}$ to NNE-SSW, determined from fault plane solutions, in agreement with the regional extensional stress pattern, which strikes perpendicular to the orientation of the main WNW-ESE active faults of the area.
\end{abstract}

Key words microseismicity - fault plane solutions active tectonics - Northern Greece

\section{Introduction}

The city of Thessaloniki is the second largest city in the territory of Greece surrounded by several small towns and villages. It has suffered significant damage due to strong earthquakes several times in the past, the most severe being in $1759(M=6.5)$ when the majority of the inhabitants abandoned the city for about two years (Papazachos and Papazachou, 2003). The 1978 Thessaloniki earthquake $(M=6.5)$

Mailing address: Dr. Parthena M. Paradisopoulou, Department of Geophysics, School of Geology, Aristotle University of Thessaloniki, GR-54124, Thessaloniki, Greece; e-mail: popi.paradis@gmail.com was the latest destructive one, causing the collapse of buildings and loss of life in the city and nearby villages. After this earthquake, seismological (Papazachos et al., 1979 a,b; Carver and Bollinger, 1981; Soufleris and Steward, 1981; Soufleris et al., 1982) and neotectonic (Mountrakis et al., 1983, 1996a,b; Mercier et al., 1983; Pavlides et al., 1990; Tranos, 1998; Tranos et al., 2003) research was carried out in the broader Thessaloniki area, trying to shed more light on the faulting pattern and the associated seismic activity of the area which belongs to the extensional Northern Aegean region (fig. 1).

The continuous recordings from the permanent seismological network installed in the area after the 1978 mainshock and fully operating since 1981 by the Geophysics Department of the Aristotle University of Thessaloniki has significantly enriched the seismological data base for that area. In addition, temporarily installed dense local networks (Hatzfeld et al., 1986/1987; Scordilis et al., 1989; Hatzidimitriou et al., 1991; Pa- 


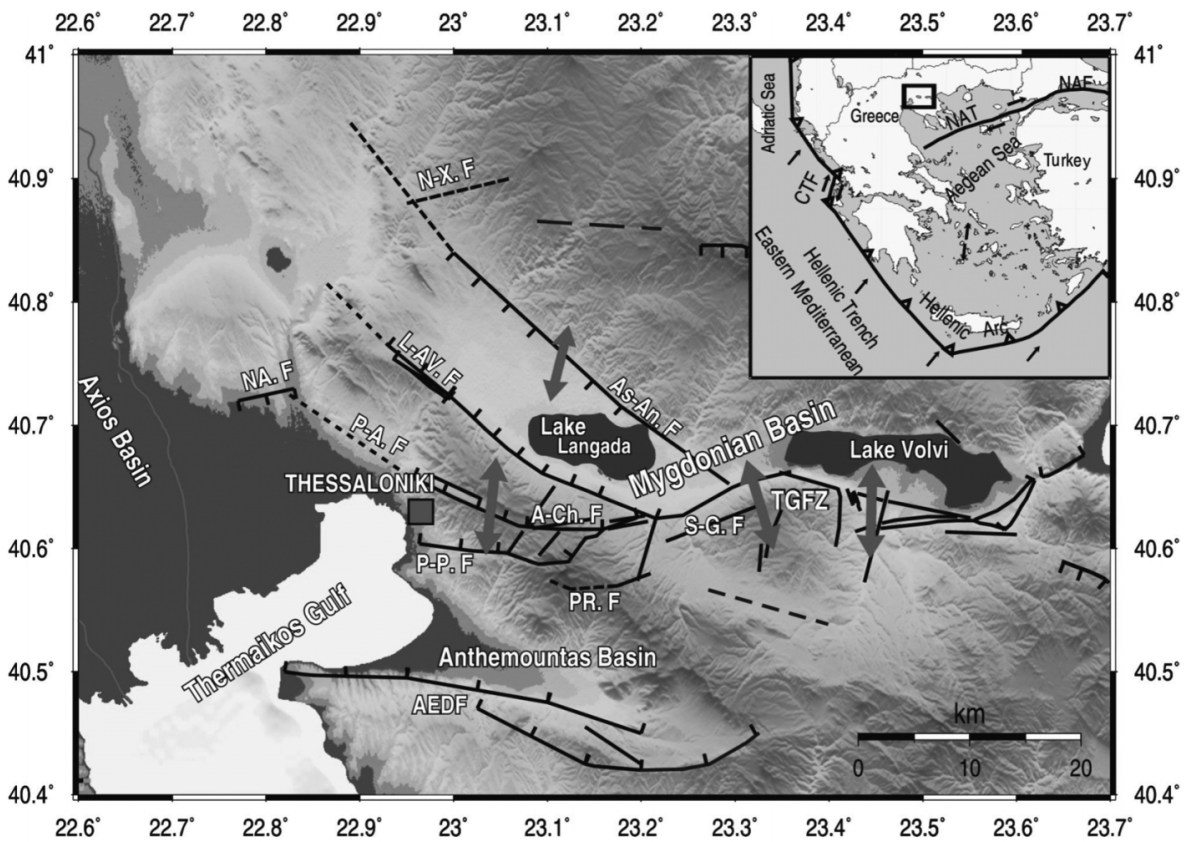

Fig. 1. Morphology and main regional faults (after Tranos et al., 2003) of the study area (N-X. F: NikopolisXilopolis Fault; As-An F.: Assiros-Analipsi Fault; L-AV F: Lagina-Ag. Vasilios Fault; NA. F: Nea Aghialos Fault; P-A F: Pefka-Asvestochori Fault; PR. F: Peristera Fault; A-Ch. F: Asvestochori-Chortiatis Fault; P-P F: Pilea-Panorama Fault; AEDF: Anthemountas Fault; S-G. F: Stivos-Gerakarou Fault). The grey arrows show the extensional velocities estimated for the Mygdonian Basin from Papazachos et al. (2001). The inset map shows main tectonic features of the Aegean and surrounding regions (CTF: Cephalonia Transform Fault; NAT: North Aegean Trough; NAF: North Anatolian Fault). The arrows show the direction of maximum compression axis from continental collision to the north and oceanic subduction to the south. The arrows at the north-east part show the strike-slip motion along the NAT which is the westward continuation of the NAF zone. The rectangle depicts the study area.

pazachos et al., 2000; Paradisopoulou et al., 2004) also provided more accurate and detailed information on the seismotectonic properties of the area. The rather weak seismic activity recorded by the permanent network (with earthquake magnitudes up to 5.1) in the vicinity of the city of Thessaloniki, do not identify active structures and their geometrical and kinematic properties or define the association of seismicity with already known active faults. Although microseismicity recorded by local networks is not as representative as the strong earthquake occurrence for the study of major tectonic features, it is a powerful tool for the identification of active structures and their properties. Its recordings permit more accurate earthquake location and the derived fault plane solutions could be used for a more detailed investigation aiming to identify the active structures of the study area.

\section{Tectonic regime}

The study region consists of elongated hilly to mountainous chains striking NW-SE and large basins and grabens that interrupt these chains. The exposed rocks are pre-Alpine and Alpine that resemble formations of Axios, Circum Rhodope belt and Serbomacedonian massif and made up the Circum Rhodope Belt Thrust Zone. This thrust zone is formed by successive anticlinoria and synclinoria that have been interrupted 
by repeated SW directed thrusts. Above this basement, extensive NW-SE and E-W striking continental-type basins and grabens have been filled with Neogene and Quaternary sediments i.e. the NW-SE Pre-Mygdonian Basin, and the E-W Anthemountas and Mygdonia basins (Tranos et al., 1999) (fig. 1). The formation of these basins is attributed to the well established brittle extensional deformation, since the Late Miocene, mainly related to high-angle normal faults (Pavlides and Kilias, 1987; Tranos, 1998; Tranos et al., 2003). This extensional deformation has the least principal stress axis $(\sigma 3)$ oriented NE$\mathrm{SW}$ in Late Miocene-Pliocene and N-S in the Quaternary (Pavlides and Kilias, 1987; Mercier and Carey-Gaihardis, 1989; Pavlides et al., 1990; Tranos, 1998; Tranos and Mountrakis, 1998). However, the fault pattern of the broader area is more complicated than initially thought and includes NW-SE, NE-SW, E-W and NNE-SSW striking faults. Many of them are inherited structures, active at least since the Miocene (Pavlides and Kilias, 1987; Tranos et al., 1999, 2003). The recent neotectonic mapping carried out in the broader Thessaloniki city (Mountrakis et al., 1996a,b; Tranos et al., 2003, 2004) recognize the following (fig. 1):

a) E-W and ENE-WSW striking PileaPanorama Fault (P-P. F), Peristera Fault (PR. F), Asvestochori-Chortiatis Fault (A-Ch. F) and Pefka-Asvestochori Fault (P-A. F). The faults are segments of the recently defined complicated fault zone named Thessaloniki-Gerakarou fault zone that strikes E-W from the city of Thessaloniki towards the Stivos-Gerakarou Fault (S-G. F) activated in 1978 .

b) NW-SE striking Lagina-Ag. Vasilios Fault (L-AV. F).

c) NW-SE striking Assiros-Analipsi Fault (As-An. F).

d) WNW-ESE striking Anthemountas Extensional Detachment Fault (AEDF), and

e) Nikopolis-Xilopolis Fault system (N-X. F).

These studies revealed that the E-W-striking faults are the most active ones associated with the current seismic activity i.e. Thessaloniki-Gerakarou Fault Zone (TGFZ) (Tranos et al., 2003) or recognized Quaternary activity, i.e. Anthemountas Fault (AEDF, fig. 2) (Mountrakis et al., 1996a,b).
Historical strong earthquakes mainly occurred along the Mygdonia Basin and Anthemountas fault zone (AEDF) and were ascribed to the reactivation of the NW-SE and E-W striking boundary faults of the basins. Similarly, the latest 1978 Thessaloniki earthquake was attributed to the Stivos-Gerakarou Fault bounding the southern part of the Mygdonia Basin. The present study correlated the possibly active faults being well defined from the neotectonic studies with the seismological data in an attempt to identify the active rupture zones of the area.

\section{Data processing}

A dense temporary network of twelve portable digital seismological stations was installed and operated during July 2001-April 2002 and October 2002-August 2003 in the area around the city of Thessaloniki. The seismic network consisted of Reftek 72A-07 seismographs, equipped with 3-component broadband seismometers (Guralp CMG40T), all connected to GPS for time correction. The average spacing between the stations was $\sim 10 \mathrm{~km}$ in order to ensure the accurate estimations of the focal depths and to allow a good coverage of first motion polarities. Figure 2 shows the position of the seismological stations along with their code names.

During the operation period, an adequate number of events were recorded both by the local and the permanent network of Geophysics Department of Thessaloniki University. Eight of the seismological stations of this seismological network are located at distances less than $100 \mathrm{~km}$ around the city. Since earthquake locations are important for the seismotectonic interpretation of an area, attention must be given to the accuracy of the locations to relate the seismicity with geological features. $P$ - and $S$-arrival times and the waveform durations were picked from stations of both networks. With this process, 398 earthquakes were identified, and eventually those with clear phase arrivals that have been recorded from at least 4 stations were used in the present analysis.

Our data set consists of 277 earthquakes with at least $4 P$ - and $1 S$-arrivals, which were located using the Hypo71 (revised) computer 


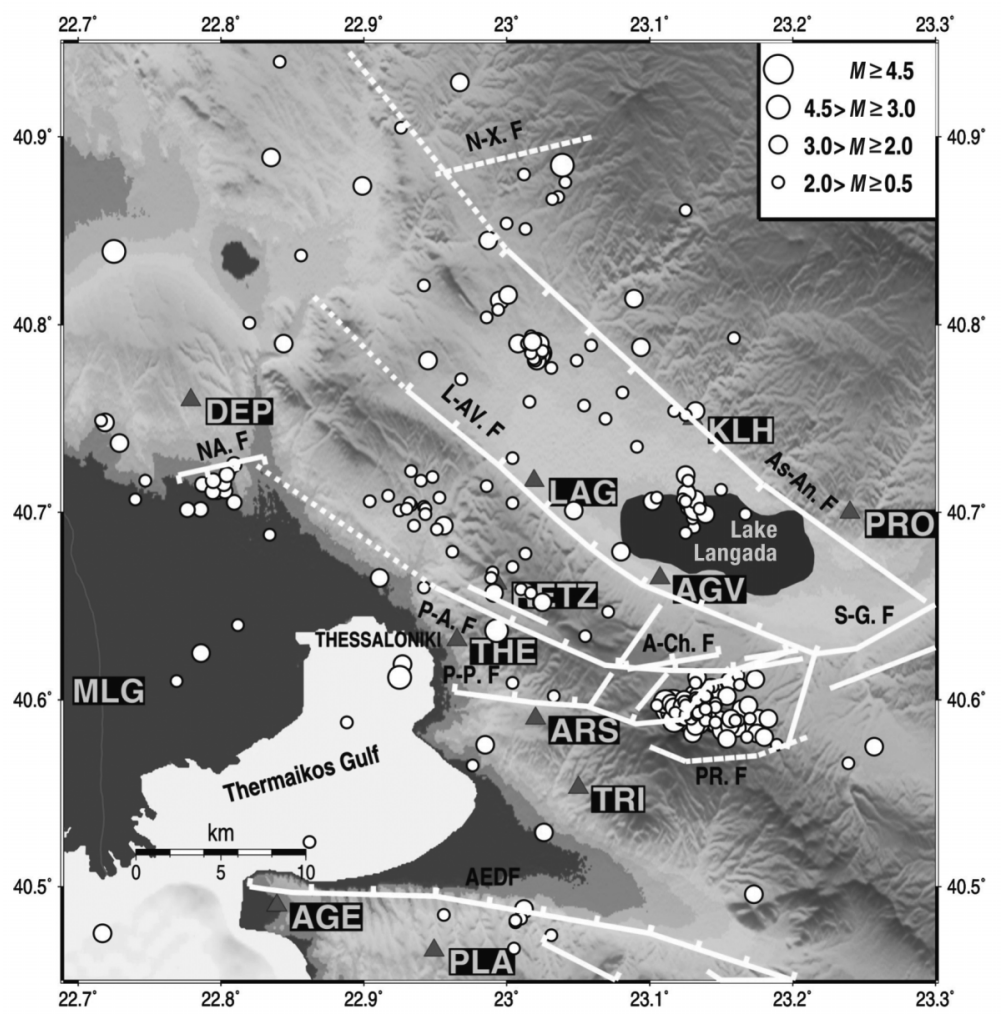

Fig. 2. Epicentral distribution of 277 earthquakes that were recorded during the operation period in more than four stations. Also the morphology and main regional faults are shown. Triangles denote the positions of the twelve seismological stations along with their code names, and circles the earthquake epicenters that occurred in the study area during July 2001-April 2002 and October 2002-August 2003. Symbol sizes are proportional to earthquakes magnitude. The symbols and the abbreviations of the faults are as in fig. 1.

program (Lee and Lahr, 1975). To ensure accurate earthquake location a local velocity model was sought. Two such models have been proposed for the broader Thessaloniki area (Hatzfeld et al., 1986/1987; Papazachos et al., 2000) and were used to locate 18 earthquakes that had clear $P$ - and $S$-arrivals and were recorded by at least seven stations. It was observed that the root-mean square values of the time error were almost the same for both models. In order to minimize the root-mean square value each model was empirically modified several times. Finally an overlying upper layer with a velocity of $4 \mathrm{~km} / \mathrm{s}$ and a thickness of 1 $\mathrm{km}$ was added to a nine layer model which had been proposed by Papazachos et al. (2000). The
Table I. $P$-wave velocity model used for the hypocenter determination (modified from Papazachos et al., 2000).

\begin{tabular}{cc}
\hline \hline$P$-wave velocity $(\mathrm{km} / \mathrm{s})$ & Depth $(\mathrm{km})$ \\
\hline 4.00 & 0.00 \\
5.29 & 1.00 \\
5.36 & 1.50 \\
5.76 & 2.00 \\
5.79 & 3.00 \\
6.16 & 4.00 \\
6.23 & 6.00 \\
6.27 & 8.00 \\
6.30 & 10.00 \\
6.42 & 20.00 \\
\hline
\end{tabular}


finally adopted crustal model is presented in table I. From the data sample a $v_{p} / v_{s}$ value equal to 1.76 was estimated. The focal parameters of the full dataset comprising 277 earthquakes were estimated with an average rootmean-square value (rms) of $0.10 \mathrm{~s}$ (fig. 3a). The horizontal (ERH) and vertical (ERZ) uncertainties in the hypocenter locations were less than 2 $\mathrm{km}$ (fig. 3b,c respectively). Most earthquakes have focal depths between 2 and $12 \mathrm{~km}$ with an average equal to $7 \mathrm{~km}$ (fig. $3 \mathrm{~d}$ ).

Local magnitudes of the earthquakes recorded from both the local and the permanent network were taken from the routinely compiled catalogue of the Geophysics Department of Thessaloniki University. For the earthquakes recorded from the local network and not located by the permanent one, amplitudes and durations on the seismograms were measured from the recordings of the Thessaloniki permanent station. Appropriate formula (Scordilis, 1985) was used for the local magnitude determination, which was subsequently converted to equivalent moment magnitudes $\left(M_{w}^{*}\right)$ according to Papazachos et al. (1997). The obtained magnitudes range for $1.0 \leq M_{w}^{*} \leq 4.5$. Figure 4 shows the magnitude distribution exhibiting completeness for earthquakes of $M_{w}^{*} \geq 2.0\left(M_{L} \geq 1.5\right)$.

The epicentral distribution of the 277 earthquakes (fig. 2) covers a broad area around Thessaloniki forming several distinct spatial clusters, some of them being clustered also in time.
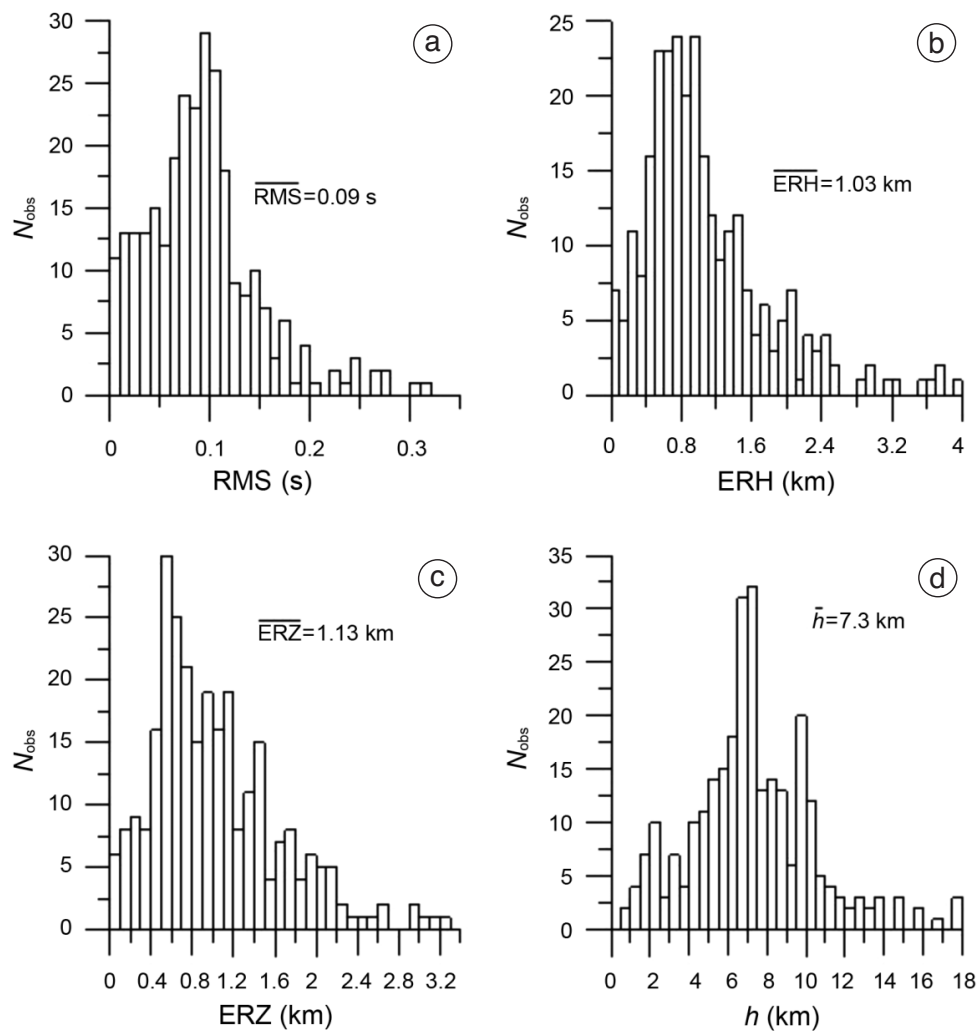

Fig. 3a-d. Histograms of a) the root-mean square of the time errors, RMS; b) the horizontal, ERH; c) vertical, ERZ, uncertainties of the hypocentral determination, and d) focal depths of the located events. 


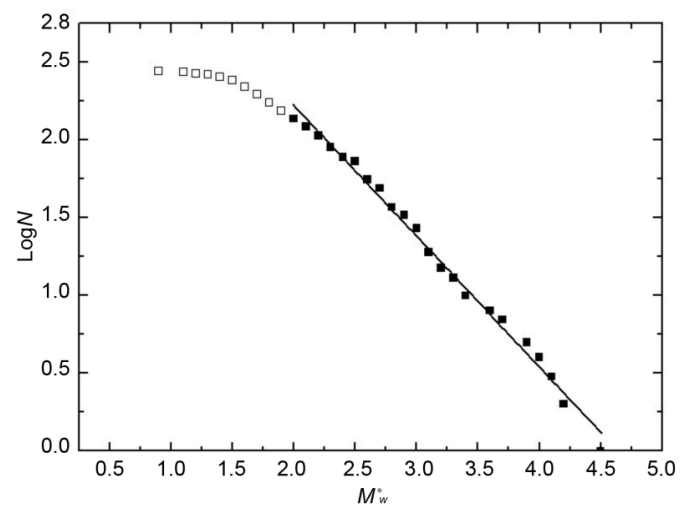

Fig. 4. Magnitude distribution of the located events. The data sample seems to be complete for magnitudes $M_{w}^{*} \geq 2.0$.
In general, the epicentral distribution follows the NW-SE grabens mentioned above. In a more detailed view, the earthquake clusters are aligned either WNW-ESE or E-W, forming en échelon structures that follow the NW-SE trend.

Reliable fault plane solutions for events recorded at least at ten stations from both the local and the permanent networks were determined by using the FPFIT program (Reasenberg and Oppenheimer, 1985). We have calculated 64 fault plane solutions, listed in table II and shown in fig. 5. The majority of them exhibit nodal planes that strike E-W to WNW-ESE (mean strike $\sim 104^{\circ}$ ) and reveal slip vectors that align with the NNE-SSW orientation. They indicate that the study area is characterised by a prevailing extensional faulting driven by an extensional strain

Table II. Fault plane solutions for 64 microearthquakes. The strike $\left(\xi^{\circ}\right)$, dip $\left(\delta^{\circ}\right)$ and rake $\left(\lambda^{\circ}\right)$ correspond to the one nodal plane of the focal mechanism. The dip and azimuth of the $P$ - and $T$-axis for each earthquake are given in last four columns.

\begin{tabular}{|c|c|c|c|c|c|c|c|c|c|c|c|c|c|c|}
\hline $\mathrm{a} / \mathrm{a}$ & Year & Date & Origin & $\phi\left({ }^{\circ} \mathrm{N}\right)$ & $\lambda\left({ }^{\circ} \mathrm{E}\right)$ & Depth & $M_{w}^{*}$ & $\xi\left({ }^{\circ}\right)$ & $\delta\left(^{\circ}\right)$ & $\lambda\left({ }^{\circ}\right)$ & $F-\mathrm{dx}$ & & $T$-axi & \\
\hline & & & time & & & $(\mathrm{km})$ & & & & & Azimuth & Dip & Azimuth & Dip \\
\hline 1 & 2001 & 22-Jul & $15: 21: 15$ & 40.737 & 22.729 & 16.55 & 2.6 & 80 & 68 & -98 & 350 & 56 & 170 & 34 \\
\hline 2 & 2001 & 0-Aug & $21: 49: 39$ & 40.673 & 23.376 & 18.41 & 3.7 & 102 & 60 & -74 & 48 & 70 & 180 & 14 \\
\hline 3 & 2001 & 11-Aug & $18: 44: 49$ & 40.662 & 23.435 & 17.82 & 3.1 & 128 & 52 & -30 & 38 & 64 & 218 & 26 \\
\hline 4 & 2001 & 21-Aug & $06: 01: 22$ & 40.720 & 23.125 & 4.12 & 2.3 & 132 & 58 & -30 & 98 & 42 & 4 & 4 \\
\hline 5 & 2001 & 28-Aug & $23: 58: 30$ & 40.889 & 22.835 & 15.07 & 2.2 & 90 & 50 & -98 & 360 & 65 & 180 & 25 \\
\hline 6 & 2001 & 3-Sep & 10:04:16 & 40.679 & 23.080 & 10.32 & 2.3 & 132 & 56 & -30 & 42 & 62 & 222 & 28 \\
\hline 7 & 2001 & 15-Sep & $17: 47: 13$ & 40.813 & 22.995 & 11.23 & 2.7 & 130 & 48 & -35 & 142 & 52 & 357 & 33 \\
\hline 8 & 2001 & 15-Sep & $20: 09: 52$ & 40.816 & 23.001 & 12.43 & 2.4 & 132 & 44 & -30 & 111 & 49 & 3 & 15 \\
\hline 9 & 2001 & 28-Sep & $21: 06: 37$ & 40.657 & 22.991 & 10.50 & 2.0 & 114 & 60 & -44 & 78 & 51 & 173 & 4 \\
\hline 10 & 2001 & 8-Oct & $04: 50: 21$ & 40.596 & 23.116 & 13.70 & 4.5 & 70 & 34 & -124 & 20 & 65 & 200 & 25 \\
\hline 11 & 2001 & 8-Oct & $05: 25: 31$ & 40.597 & 23.143 & 14.18 & 2.5 & 110 & 50 & -98 & 258 & 68 & 6 & 7 \\
\hline 12 & 2001 & 8-Oct & $05: 26: 44$ & 40.593 & 23.116 & 13.68 & 4.1 & 74 & 42 & -122 & 323 & 72 & 181 & 14 \\
\hline 13 & 2001 & 8-Oct & $05: 28: 44$ & 40.595 & 23.164 & 13.73 & 2.6 & 82 & 60 & -102 & 360 & 72 & 180 & 18 \\
\hline 14 & 2001 & 8-Oct & $05: 29: 28$ & 40.589 & 23.145 & 14.40 & 3.4 & 90 & 36 & -100 & 302 & 70 & 195 & 6 \\
\hline 15 & 2001 & 8-Oct & $05: 32: 16$ & 40.589 & 23.126 & 13.57 & 3.9 & 88 & 54 & -114 & 247 & 69 & 355 & 7 \\
\hline 16 & 2001 & 8-Oct & $05: 36: 20$ & 40.588 & 23.148 & 13.78 & 3.1 & 64 & 42 & -120 & 260 & 69 & 166 & 2 \\
\hline 17 & 2001 & 8-Oct & $06: 52: 48$ & 40.593 & 23.124 & +14.78 & 3.3 & 56 & 50 & -118 & 360 & 67 & 180 & 23 \\
\hline 18 & 2001 & 8-Oct & $06: 55: 29$ & 40.599 & 23.111 & 13.23 & 3.2 & 90 & 46 & -104 & 20 & 67 & 200 & 23 \\
\hline 19 & 2001 & 8-Oct & $07: 04: 27$ & 40.588 & 23.133 & 13.14 & 3.0 & 110 & 46 & -58 & 335 & 81 & 200 & 7 \\
\hline 20 & 2001 & 8-Oct & $07: 15: 19$ & 40.588 & 23.134 & +14.10 & 3.0 & 104 & 52 & -98 & 346 & 60 & 166 & 30 \\
\hline 21 & 2001 & 8-Oct & $07: 16: 09$ & 40.593 & 23.128 & 14.18 & 2.9 & 76 & 60 & -104 & 6 & 71 & 186 & 19 \\
\hline 22 & 2001 & 8-Oct & $07: 25: 54$ & 40.591 & 23.125 & 14.56 & 2.9 & 96 & 38 & -92 & 308 & 67 & 206 & 5 \\
\hline
\end{tabular}


Table II (continued).

\begin{tabular}{|c|c|c|c|c|c|c|c|c|c|c|c|c|c|c|}
\hline $\mathrm{a} / \mathrm{a}$ & Year & Date & & $\phi\left({ }^{\circ} \mathrm{N}\right)$ & $\lambda\left({ }^{\circ} \mathrm{E}\right)$ & & $M_{w}^{*}$ & $\xi\left(^{\circ}\right)$ & $\delta\left(^{\circ}\right)$ & $\lambda\left({ }^{\circ}\right)$ & $P$ & & & \\
\hline & & & 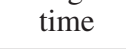 & & & m) & & & & & Azimuth & Dip & Azimuth & Dip \\
\hline 23 & 2001 & 8-Oct & $07: 26: 32$ & 40.596 & 23.117 & 14.76 & 2.8 & 96 & 54 & -118 & 352 & 60 & 172 & 30 \\
\hline 24 & 2001 & 8-Oct & 08:00:25 & 40.590 & 23.126 & 13.45 & 3.6 & 82 & 60 & -112 & 307 & 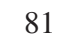 & 187 & 5 \\
\hline 25 & 2001 & 8-Oct & $08: 21: 26$ & 40.595 & 23.128 & 14.43 & 2.9 & 96 & 50 & -100 & 20 & 72 & 200 & 18 \\
\hline 26 & 2001 & 8-Oct & $13: 47: 57$ & 40.600 & 23.124 & +14.13 & 2.1 & 110 & 36 & -90 & 322 & 79 & 199 & 6 \\
\hline 27 & 2001 & 8-Oct & $13: 49: 19$ & 40.596 & 23.123 & 14.13 & 2.1 & 100 & 52 & -102 & 360 & 7 & 180 & 20 \\
\hline 28 & 2001 & 8-Oct & $19: 00: 28$ & 40.593 & 23.134 & +13.86 & 1.6 & 90 & 40 & -106 & 360 & 70 & 180 & 20 \\
\hline 29 & 2001 & 9-Oct & 06:59:05 & 40.597 & 23.169 & 16.21 & 2.7 & 90 & 40 & -108 & 20 & 7 & 200 & 19 \\
\hline 30 & 2001 & $11-$ Oct & $16: 31: 46$ & 40.584 & 23.152 & 12.75 & 3.0 & 110 & 38 & -80 & 301 & 5 & 211 & 1 \\
\hline 31 & 2001 & 14-Oct & 09:06:00 & 40.555 & 23.582 & 16.27 & 2.7 & 90 & 56 & -136 & 20 & 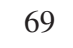 & 200 & 21 \\
\hline 32 & 2001 & $25-\mathrm{Nov}$ & 20:09: & 40.590 & 23.183 & 14.48 & 2.4 & 110 & 42 & -90 & 126 & & 7 & 21 \\
\hline 33 & 2001 & 4-Dec & $17: 03$ & 40.693 & 22.956 & 6.51 & 2.1 & 138 & 36 & -30 & 36 & 6 & 147 & 10 \\
\hline 34 & 2001 & 13-Dec & $08: 48$ & 40.475 & 22.717 & 13.11 & 2.5 & 76 & 58 & -64 & 115 & & 2 & 18 \\
\hline 35 & 2001 & 14-Dec & $22: 39: 00$ & 40.791 & 23.018 & 13.07 & 2.1 & 132 & 40 & -30 & 156 & 5 & 11 & 33 \\
\hline 36 & 2002 & 17-Jan & 06: & 40.781 & 22.945 & 14.28 & 2.2 & 148 & 20 & -30 & 240 & & 12 & 8 \\
\hline 37 & 2002 & $24-\mathrm{Feb}$ & $09: 31: 13$ & 40.929 & 22.967 & 19.65 & 2.5 & 92 & 38 & -104 & 64 & 6 & 176 & 11 \\
\hline 38 & 2002 & $24-\mathrm{Feb}$ & 21:50:00 & 40.575 & 23.257 & 16.70 & 2.3 & 106 & 60 & -62 & 271 & 5 & 170 & 7 \\
\hline 39 & 2002 & 7-Mar & $08: 0$ & 40.748 & 22.719 & 19.28 & 2.8 & 54 & 60 & -128 & 10 & & 190 & 12 \\
\hline 40 & 2002 & 18 & $10:$ & 40.609 & 23.005 & 12.90 & 1.5 & 100 & 24 & -98 & 69 & 5 & 170 & 7 \\
\hline 41 & 2002 & 13-Apr & $08: 1$ & 40.702 & 23.132 & 10.27 & 3.0 & 106 & 60 & -52 & 343 & & 195 & 14 \\
\hline 42 & 2002 & 13-Apr & 08:13: & 40.707 & 23.133 & 10.55 & 3.0 & 98 & 60 & -100 & 71 & 60 & 176 & 9 \\
\hline 43 & 2002 & 13-Apr & 13: & 40.710 & 23.127 & 10.02 & 2.2 & 110 & 60 & -56 & 1 & & 196 & 30 \\
\hline 44 & 2002 & 13-Apr & 17: & 40.699 & 23.139 & 10.63 & 2.3 & 128 & 60 & -30 & 76 & 4 & 169 & 2 \\
\hline 45 & 2002 & 13-Apr & 21:06: & 40.706 & 23.126 & 9.64 & 1.7 & 112 & 60 & -4 & 89 & & 180 & 1 \\
\hline 46 & 2002 & 16-Apr & $11: 11$ & 40.682 & 23.169 & 8.01 & 2.7 & 124 & 60 & -38 & 237 & 6 & 4 & 15 \\
\hline 47 & 2003 & $29-O c t$ & 21: & 40.702 & 22.785 & 10.80 & 4.5 & 76 & 70 & -140 & 3 & 5 & 166 & 35 \\
\hline 48 & 2002 & $21-\mathrm{Oct}$ & 09:10:07 & 40.706 & 23.102 & 9.62 & 2.1 & 150 & 40 & -42 & 60 & 0 & 240 & 20 \\
\hline 49 & 2002 & 4-Nov & 01:01: & 40.791 & 23.021 & 11.97 & 2.5 & 142 & 20 & -30 & 52 & 8 & 232 & 10 \\
\hline 50 & 2002 & $24-\mathrm{Nov}$ & $19: 43: 34$ & 40.754 & 23.132 & 13.67 & 2.2 & 140 & 40 & -44 & 50 & 7 & 230 & 20 \\
\hline 51 & 2002 & $25-\mathrm{Nov}$ & 00: & 40.754 & 23.125 & 13.37 & 1.9 & 106 & 36 & -30 & 16 & 7 & 196 & 18 \\
\hline 52 & 2002 & $15-1$ & 04: & 40.619 & 22.927 & 14.75 & 2.2 & 96 & 50 & -96 & 6 & & 186 & 25 \\
\hline 53 & 2002 & 18-Dec & $11: 29: 33$ & 40.757 & 23.054 & +11.47 & 1.8 & 132 & 40 & -48 & 42 & 70 & 222 & 20 \\
\hline 54 & 2003 & 1-Jan & 04:48:00 & 40.717 & 22.747 & 10.33 & 1.1 & 84 & 60 & -150 & 354 & 6 & 174 & 30 \\
\hline 55 & 2003 & 6-Jan & $17: 34: 00$ & 40.764 & 23.081 & 9.05 & 1.4 & 120 & 46 & -48 & 30 & 67 & 210 & 23 \\
\hline 56 & 2003 & 10-Jan & $11: 38: 30$ & 40.679 & 22.962 & 2.95 & 1.3 & 118 & 40 & -110 & 28 & 7 & 208 & 20 \\
\hline 57 & 2003 & 11-Jan & $10: 01: 28$ & 40.699 & 23.131 & 4.12 & 1.4 & 110 & 28 & -46 & 20 & 76 & 200 & 14 \\
\hline 58 & 2003 & 12-Jan & $15: 47: 04$ & 40.854 & 23.000 & 7.39 & 1.6 & 108 & 44 & -108 & 18 & 68 & 198 & 22 \\
\hline 59 & 2003 & 18-Jan & 14:10:42 & 40.718 & 22.449 & 19.49 & 2.0 & 112 & 20 & -64 & 22 & 80 & 202 & 10 \\
\hline 60 & 2003 & 4-Feb & 04:12:08 & 40.640 & 22.812 & 8.46 & 1.7 & 144 & 28 & -48 & 54 & 76 & 234 & 14 \\
\hline 61 & 2003 & 9-Feb & $02: 10: 36$ & 40.821 & 22.942 & 1.04 & 1.9 & 104 & 24 & -110 & 14 & 78 & 194 & 12 \\
\hline 62 & 2003 & $10-\mathrm{Feb}$ & 05:09:24 & 40.659 & 23.440 & 21.21 & 2.9 & 148 & 22 & -148 & 58 & 79 & 238 & 11 \\
\hline 63 & 2003 & $10-\mathrm{Feb}$ & $15: 46: 52$ & 40.372 & 22.653 & 3.19 & 1.8 & 96 & 60 & -150 & 6 & 60 & 186 & 30 \\
\hline 64 & 2003 & $10-\mathrm{Feb}$ & $18: 12: 37$ & 40.801 & 22.820 & 5.40 & 1.7 & 106 & 20 & -126 & 16 & 80 & 196 & 10 \\
\hline
\end{tabular}




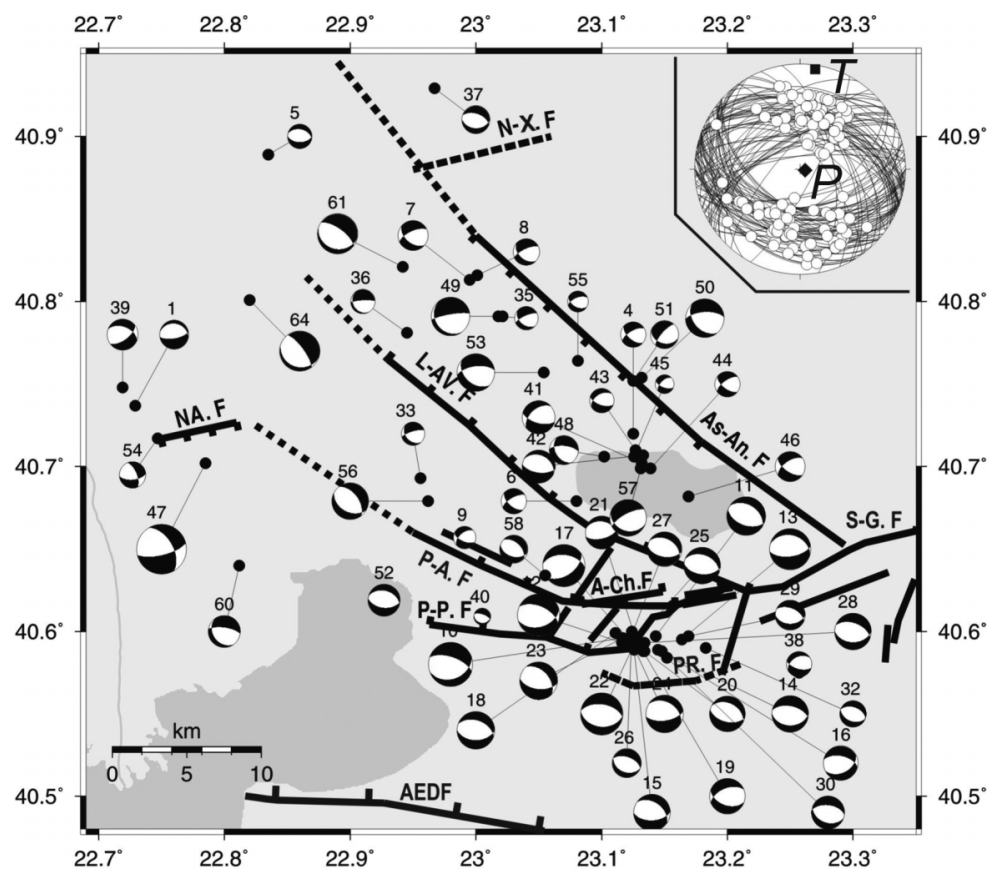

Fig. 5. Fault plane solutions shown as equal-area lower hemisphere projections. The numbers correspond to the time order of earthquake occurrence (table II). The balloon size is a function of the earthquake magnitude. Compressional quadrants are shaded. The inset shows the nodal planes considered as the fault planes, the corresponding slip vectors and the mean position of $T$ - and $P$-axes. The symbols and the abbreviations of the faults are as in fig. 1.

regime, in accordance with previously published fault plane solutions (Papazachos et al., 1979b; Carver and Bollinger, 1981; Soufleris et al., 1982, 1983; Hatzfeld et al., 1986/1987; Hatzidimitriou et al., 1991).

\section{Seismotectonic analysis}

The earthquakes' spatial distribution, fault plane solutions and neotectonic information were combined to recognize the seismotectonic properties of the study area. Earthquake locations from previous local experiments (Hatzfeld et al., 1986/1987; Hatzidimitriou et al., 1991; Papazachos et al., 2000) were taken into account. Earthquakes are considered in clusters defined by polygons and assigned to specific fault segments (fig. 6). The shape of each polygon was selected to fit the trend of the cluster, the strike of the nearest fault segment and the focal mechanisms of the earthquakes occurred inside the polygon, and particularly that of the largest earthquake of the cluster. Cross sections trending perpendicular to the mean strike of the respective fault segment were made, trying to identify the possible relationship between the microearthquake clusters and the known active faults. It must be mentioned that in this procedure only the earthquakes inside each polygon were considered.

The Nea Aghialos swarm (polygon A in fig. 6) consists of 13 earthquakes that occurred at a distance of $15 \mathrm{~km} \mathrm{NW}$ of the city of Thessaloniki, close to the Nea Aghialos village. The larger earthquake with $M_{w}^{*}=4.5$ occurred on 29 October 2003 and the seismic sequence continued for twelve days. At this period the local network was not operational for software upgrade 
purposes. The earthquakes of the seismic sequence were recorded from the permanent network, from at least 5 stations located near Thessaloniki. Using HypoDD program (Waldhauser, 2001) from 34 recorded earthquakes only 13 were selected with at least four $P$ - and one $S$-arrivals and their locations were determined with the mean rms error. The aftershock spatial distribution shows an ENE-WSW trend and focal depths range between 2 and $10 \mathrm{~km}$. The fault plane solutions of the earthquakes in this area (No. 1, 39, 47, 54 in table II and fig. 5) and the alignment of the hypocenters in the cross-section (fig. 7A) indicate that the rupture zone, namely Nea Aghialos Fault (NA. F) strikes ENE-WSW $\left(\sim 80^{\circ}\right)$ and dips at $70^{\circ}$ to SSE, reaching a depth of $12 \mathrm{~km}$. The only geological information (Tranos, 2002) available for this area refers to the existence of an E-W striking fault that dips at a high angle to the $\mathrm{S}$.

The Efkarpia-Asvestochori cluster (polygon $\mathrm{B}$ in fig. 6) comprises several microearthquakes that disperse along the mountainous Chortiatis region showing a WNW-ESE preferred orientation and with focal depth ranging up to $15 \mathrm{~km}$. The nodal planes of the determined focal mechanisms (No. 9, 33, 40, 56, 58 in table II and fig. 5) strike WNW-ESE with a mean value of $130^{\circ}$. Taking into account the corresponding crosssection (fig. 7B), this rupture zone should dip at about $50^{\circ}$ to the NE, in good agreement with the NW-SE $\left(130^{\circ}\right)$ striking Pefka-Asvestochori

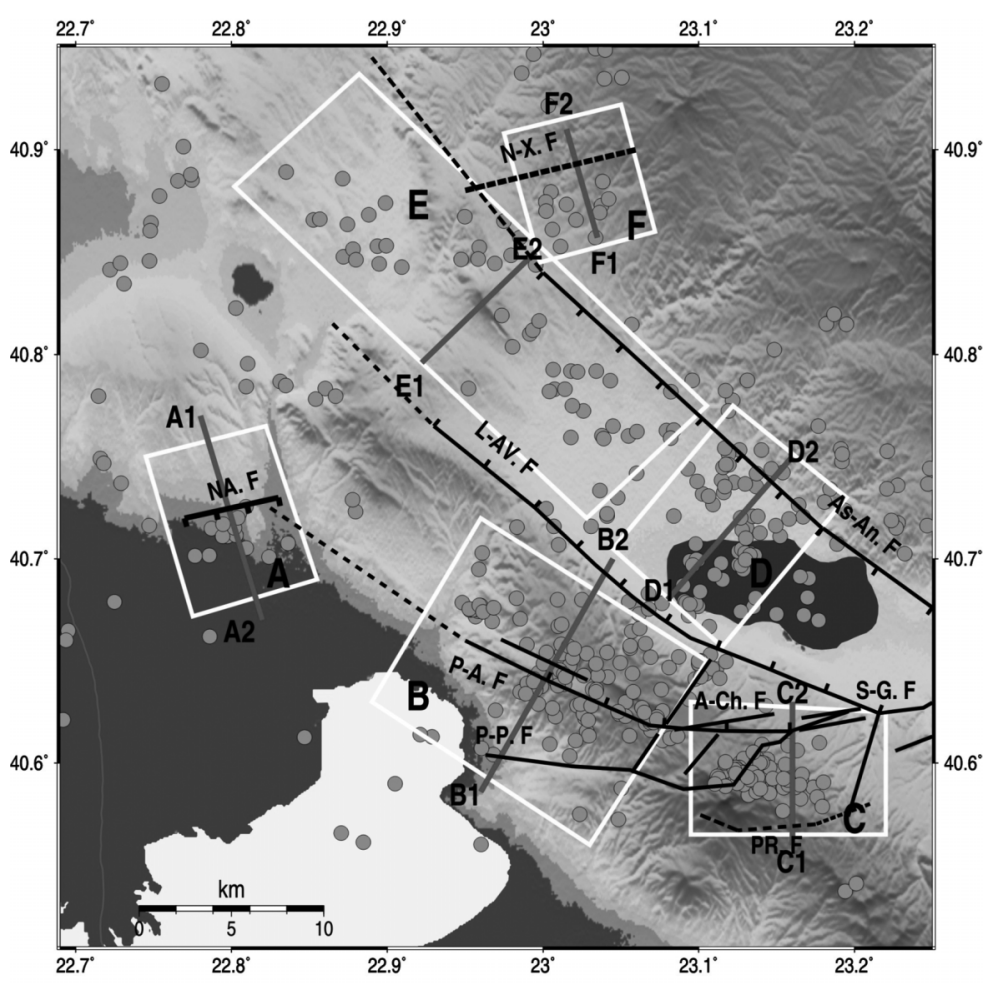

Fig. 6. Epicentral distribution of the earthquakes recorded by the local experiments (Hatzfeld et al., 1986/1987; Hatzidimitriou et al., 1991; Papazachos et al., 2000 and the experiment carried out in June 2001-April 2002 and October 2002-August 2003). White polygons enclose the clusters for which cross sections were performed. The hypocentres included in each polygon were projected onto the lines that are perpendicular to the strike of the corresponding fault segment. 

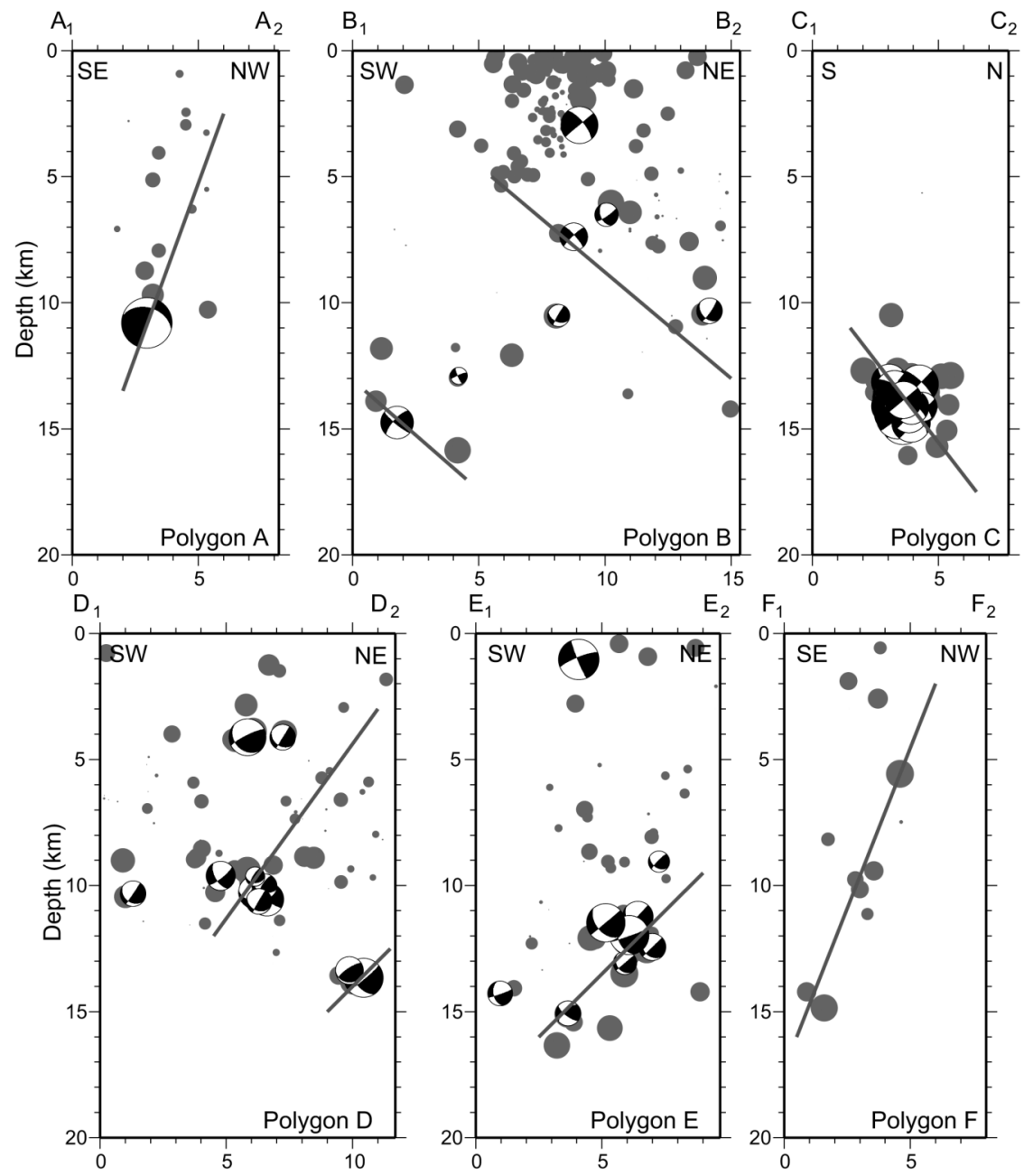

Fig. 7. Depth section of the earthquakes within the six boxes shown in fig. 6. Gray lines depict the fault dip. The mechanisms are shown as equal area projections of the front hemisphere.

Fault segment (P-A. F) of the Thessaloniki-Gerakarou Fault Zone (TGFZ) that dominates in the area and dips to NNE (Tranos et al., 2003). A few earthquakes located at larger depths (10-15 $\mathrm{km})$ are probably associated with a smaller fault parallel to the Pilea-Panorama Fault (P.-P. F).

The cluster in Chortiatis mountainous area includes about 50 earthquakes that form a WNW-ESE to E-W trending seismic band (polygon $\mathrm{C}$ in fig. 6). A seismic sequence oc- curred in this area with a main shock of $M=4.5$ on 8 October 2001 and lasted for six days. The focal mechanisms (No. 10-32 in table II and fig. 5) have nodal planes striking WNW-ESE with a mean value of $114^{\circ}$ and dip angles of about $50^{\circ}$. The cross-section (fig. 7C), which is perpendicular to the strike of the Thessaloniki-Gerakarou Fault Zone (TGFZ) indicates an eastward prolongation of the Pilea-Panorama Fault (dashed line in fig. 6, PR. F). 
In the cluster of polygon $\mathrm{D}$ the fault plane solutions (No. 4, 41, 42, 43, 44, 45, 46, 48, 50, and 51, in table II and fig. 5) clearly show that the one nodal plane dips at about $55^{\circ}$ towards $\mathrm{SW}$, and the other dips about $60^{\circ}$ towards NW. Focal mechanisms along with the cross-section (fig. 7D) reveal an active structure that strikes NW-SE and dips at $55^{\circ}$ towards SW, probably associated with the Assiros-Analipsi Fault (AsAn. F). Additionally, its kinematics, defined by focal mechanisms is an oblique extensional movement with a right lateral strike-slip component that agrees fairly well with the kinematics suggested by neotectonic studies (Mercier et al., 1983; Mountrakis et al., 1983; Koukouvelas and Aydin, 2002).

Fault plane solutions of events inside the polygon E (fig. 6) (No. 8, 9, 35, 49, 53 and 55 in table II and fig. 5) are similar to those of the previous clusters. The distribution of the hypocenters on the SW-NE striking cross section (fig. 7E) indicates that the rupture zone dips at an angle of $\sim 45^{\circ}$ towards SW, which agrees and fits well with the northwestward extended towards NW trace of the Assiros-Analipsi Fault (As-An. F, fig. 6), indicating the association of the microseismicity with this fault.

The cluster of polygon $\mathrm{F}$ is located in an area where ENE-WSW striking faults form a fault array, named Nikopolis-Xilopolis Fault system (N-X. F) that bound very small and shallow Quaternary basins (Mountrakis et al., 1996a,b). The cross-section (fig. 7F) indicates that this active structure dips at a high angle toward SE and is rather related to south dipping faults of the aforementioned system.

The maximum extension axes $(T)$ derived from the focal mechanisms determination (fig. 8) are sub horizontal trending almost N-S, in agreement with previous investigations (Hatzfeld et al., 1986/1987; Scordilis et al., 1989; Hatzidimitriou et al., 1991; Papazachos et al., 2000). In

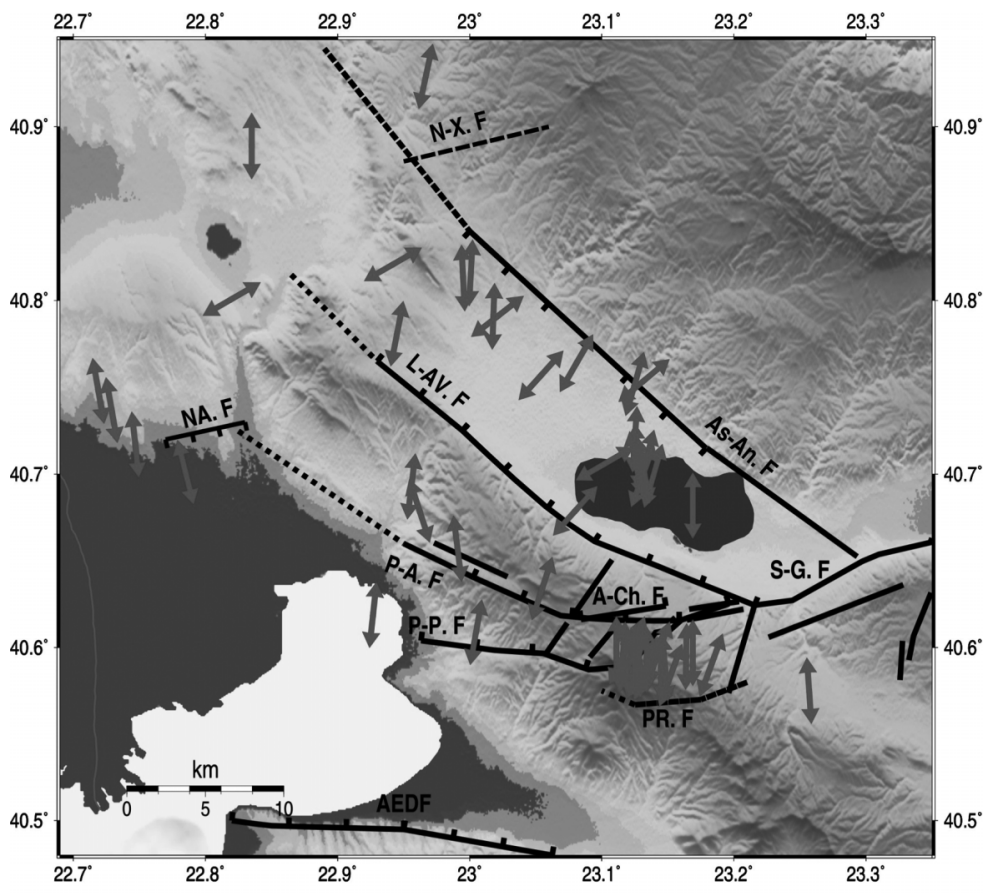

Fig. 8. Spatial distribution of the axis of maximum extension ( $T$-axis) provided by fault plane solutions. The symbols and the abbreviations of the faults are as in fig. 1 . 
particular, the mean trend of the $T$-axes has a NNW-SSE strike in the area of N. Anghialos Fault (NA-F) and along the Chortiatis mountain chain (P-P. F and A-Ch. F). To the north of the Langada Lake (D area) the mean $T$-axis trends $\mathrm{N}-\mathrm{S}$, whereas similar N-S trending has been defined for the area south of Lake Langada. However, in some cases a significant variation is observed with the orientation of the $T$-axes ranging from NNW-SSE to NE-SW. The NE-SW oriented $T$-axes are probably associated with the NWSE trending inherited structures, which can be reactivated under the dominating $\mathrm{N}-\mathrm{S}$ extension.

The results confirm a previous study $(\mathrm{Pa}-$ pazachos et al., 2001) using the combined stress pattern and the corresponding moment rate tensors. From the determination of strain and velocity tensors it was found that the corresponding extensional velocity is $0.63 \mathrm{~mm} / \mathrm{yr}$ at the northern part of the study area and $0.21 \mathrm{~mm} / \mathrm{yr}$ at the southern part (Papazachos et al., 2001).

\section{Conclusions}

A microearthquake study around the city of Thessaloniki provides additional information on the seismotectonic properties of the area. Although the epicentral distribution exhibits a NW-SE general trend, the observed clusters correlate better with the known active structures of the area, which are orientated E-W. This also advocates the fact that the majority of fault plane solutions exhibit extensional faulting along the E-W strike with the $T$-axis oriented almost N-S, in accordance with previous investigations (Papazachos et al., 1979b; Carver and Bollinger, 1981; Soufleris et al., 1982, 1983; Hatzfeld et al., 1986/1987; Hatzidimitriou et al., 1991). However, some microearthquake fault plane solutions define $T$-axes that deviate significantly from the mean $T$-axis value, possibly indicating that the inherited fault pattern partly influences the seismicity.

In addition, the present approach seems to be more important since it permits the detection of blind active faults such as the case of the Nea Anghialos Fault, where the geological information is not adequate and a recent seismic sequence occurred.
Given the fact that this study concerns one of the most populated areas in Greece, the active structures identified in this work could be taken into account in future seismic hazard assessment.

\section{Acknowledgements}

The authors express their appreciation to the reviewer for the careful inspection and constructive comments. This work was supported by the Region of Central Macedonia and $\mathrm{Mu}-$ nicipality of Thessaloniki. The GMT system (Wessel and Smith, 1998) was used to plot the figures. Geophysics Department Contribution 655.

\section{REFERENCES}

CARver, D. and G.A. Bollinger (1981): Aftershocks of the June 20, 1978, Greece earthquake: a multimode faulting sequence, Tectonophysics, 73, 343-363.

HatzFeld, D., A.A. Christodoulou, E.M. Scordilis, D. Panagiotopoulos and P.M. Hatzidimitriou (1986/ 1987): A microearthquake study of the Mygdonian graben (Northern Greece), Earth Planet. Sci. Lett., 81, 379-396.

Hatzidimitriou, P.M., D. HatzFeld, E.M. Scordilis, E.E. PAPAdimitriou and A.A. Christodoulou (1991): Seismotectonic evidence of an active normal fault beneath Thessaloniki (Greece), Terra Motae, 3, 648-654.

Koukouvelas, I.K. and A. Aydin (2002): Fault structure and related basins of the North Aegean Sea and its surroundings, Tectonics, 21, doi: 10.1029/2001TC901037.

LEE, W.H.K. and J.C. LAHR (1975): A computer program for the determining hypocenter, magnitude and first motion pattern of local earthquakes, U.S. Geol. Surv. Open File Rep., 75-311.

Mercier, J.L. and E. CAREY-Gaihardis (1989): Regional state of stress and characteristic fault kinematic instabilities shown by aftershock sequences: the aftershock sequences of the 1978 Thessaloniki (Greece) and 1980 Campania-Lucania (Italia) earthquakes as examples, Earth Planet. Sci. Lett., 92, 247-264.

Mercier, J.L., E. Carey-Gailhardis, N. Mouyaris, K. SimEAKIS, T. RoundoyanNis and C. ANGHELIDHIS (1983): Structural analysis of recent and active faults and regional state of stress in the epicentral area of the 1978 Thessaloniki earthquakes (Northern Greece), Tectonics, 2, 577-600.

Mountrakis, D., A. Psilovikos and B. PAPAZaChos (1983): The geotectonic regime of the Thessaloniki earthquakes, in The Thessaloniki, Northern Greece, Earthquake of June 20, 1978 and Its Seismic Sequence, edited by B.C. PAPAZACHOS and P.G. CARYdis, Technical Chamber of Greece, 11-27. 
Mountrakis, D., A. Kilias, S. Pavlides, L. Sotiriadis, A. Psilovikos, Th. Astaras, E. Vavliakis, G. Koufos, G. Dimopoulos, G. Soulios, V. Christaras, M. Skordilis, M. Tranos, N. Spyropoulos, D. Patras, G. SyRIDES, N. LAMBrinOS and T. LAGgalis (1996a): Neotectonic Map of Greece, Langadhas Sheet, Scale 1:100000 (Earthq. Plann. Prot. Organ. and Europ. Centre Prevent. Forecasting Earthq.).

Mountrakis, D., A. Kilias, S. PaVlides, L. Sotiriadis, A. Psilovikos, Th. Astaras, E. Vavliakis, G. Koufos, G. Dimopoulos, G. Soulios, V. Christaras, M. Skordilis, M. Tranos, N. Spyropoulos, D. Patras, G. Syrides, N. LAmbrinos and T. LAGgalis (1996b): Neotectonic Map of Greece, Langadhas Sheet, Scale 1:100000 (Earthq. Plann. Prot. Organ. and Europ. Centre Prevent. Forecasting Earthq.).

PAPAZACHOS, B.C. and C. PAPAZACHOU (2003): The Earthquakes of Greece (Ziti Publications, Thessaloniki), pp. 317.

Papazachos, B.C., D. Mountrakis, A. Psilovikos and G. LEVENTAKIS (1979a): Surface fault traces and fault plane solutions of the May-June 1978 major shocks in the Thessaloniki area, Greece, Tectonophysics, 53, 171-183.

Papazachos, B.C., A. Mountrakis, A. Psilovikos and G. LEVENTAKIS (1979b): Focal properties of the 1978 earthquakes in Thessaloniki area, Bulg. Geophys. J., 6, 72-80.

Papazachos, B.C., A.A. Kiratzi and B.G. Karakostas (1997): Toward an homogeneous moment magnitude determination in Greece and surrounding area, Bull. Seism. Soc. Am., 87, 474-483.

Papazachos, C.B., P. Soupios, A. SAvvaidis and Z. RoumeLIOTI (2000): Identification of small-scale active faults near metropolitan areas: an example from the Asvestochori fault near Thessaloniki, in Proc. XXXII ESC Gen. Ass., 15-20 September 2000, Lisbon, Portugal, 221-225.

PAPAZACHOS, C.B., D.A. VAMVAKARIS, G.N. VARGEMEZIS and E.V. AidonA (2001): A study of the active tectonics and deformation in the Mygdonia Basin ( $N$. Greece) using seismological and neotectonic data, Bull. Geol. Soc. Greece, XXXIV, 303-309.

Paradisopoulou, P.M., V.G. Karakostas, E.E. Papadimitriou, M.D. Tranos, C.B. PAPAZAChOS and G.F. KARAKAISIS (2004): Microearthquake study of the broader Thessaloniki area, in 5th Intern. Symp. East. Mediter. Geol., 14-20 April 2004, Thessaloniki, Greece, 2, 623-626.

PAVlides, S.B. and A.A. Killas (1987): Neotectonic and active faults along the Serbomacedonian zone (SE Chalkidiki, Northern Greece), Ann. Tectonicae, 1, 9-104.

Pavlides, S., D. Mountrakis, A. Kilias and M. Tranos (1990): The role of strike-slip movements in the extensional area of the Northern Aegean (Greece), in Active and Recent Strike-slip Tectonics, edited by M. BocCAlETti and A. Nur, Ann. Tectonicae, 4, 196-211.

Reasenberg, P. and D. Openheimer (1985): Fpfit (U.S. Geological Survey, Menlo Park, California).

ScordiLIS, E.M. (1985): Microseismic study of the Serbo- macedonian zone and the surrounding area, Ph.D. Thesis (University of Thessaloniki, Greece), pp. 250.

Scordilis, E.M., G. Karakaisis, E. PAPAdimitriou and B. MARGARIS (1989): Microseismicity study of the Servomacedonian zone and the surrounding area, Geologica Rhodopica, 1, 79-83.

SOUFLERIS, C. and G.S. STEWARD (1981): A source study of the Thessaloniki (Northern Greece) 1978 earthquake sequence, Geophys. J. R. Astron. Soc., 67, 343-358.

Soufleris, C., J.A. Jackson, G.C.P. King, C.P. SPENCER and C.H. Scholz (1982): The 1978 earthquake sequence near Thessaloniki (Northern Greece), Geophys. J. R. Astron. Soc., 68, 429-458.

SOUFLERIS, C., J.A. JACKSON, G.C.P. KING and C.P. SPENCER (1983): Thessaloniki 1978 Earthquakes: Locally Recorded Aftershocks. The Thessaloniki, Northern Greece Earthquake of June 201978 and its Seismic Sequence, edited by B.C. PAPAZACHOS and P.G. CARYDIS (Thessaloniki), 159-185.

Tranos, M.D. (1998): Contribution to the study of the neotectonic deformation in the Region of Central Macedonia and North Aegean, Ph.D. Thesis, (University of Thessaloniki, Greece), pp. 346 (in Greek with extended English summary).

Tranos, M.D. (2002): Geological study of the Dialogi region. Municipality of Eleftherio-Kordelio, Perfecture of Thessaloniki Report, pp. 76.

Tranos, M.D. and D.M. Mountrakis (1998): Neotectonic joints of Northern Greece: their significance on the understanding of the active deformation, Bull. Geol. Soc. Greece, 32, 209-219.

Tranos, M.D., A.A. Kilias and D.M. MounTRAKIS (1999): Geometry and kinematics of the Tertiary post-metamorphic Circum Rhodope Belt Thrust System (CRBTS), Northern Greece, Bull. Geol. Soc. Greece, 33, 5-16.

Tranos, M.D., E.E. Papadimitriou and A.A. Kilias (2003): Thessaliniki-Gerakarou Fault Zone (TGFZ): the western extension of the 1978 Thessloniki earthquake fault (Nothern Greece) and seismic hazard assessment, J. Struct. Geol., 25, 2109-2123.

Tranos, M.D., I.D. Meladiotis and E.P. Tsolakopoulos (2004): Geometrical characteristics, scaling properties and seismic behavior of the faulting of the Chortiatis region and Anthemountas Basin (Northern Greece), in 5th Intern. Sympos. Eastern Mediterranean Geology, Thessaloniki, Greece, edited by A.A. ChatzIPETros and S.B. PAVLIDES, 2, 889-891.

WALDHAUSER, F. (2001): A program to compute double-difference hypocenter locations, U.S. Geol. Surv. Open File Rep., 1-113.

Wessel, P. and W.H.F. SMITH (1998): New, improved version of the generic mapping tools released, Eos Trans. Am. Geophys. Un., 79, 579.

(received January 25, 2006 accepted April 4, 2006) 